Board of Governors of the Federal Reserve System

International Finance Discussion Papers

Number 816

August 2004

Corporate Governance and the Shareholder Base

Karl V. Lins and Francis E. Warnock

NOTE: International Finance Discussion Papers are preliminary materials circulated to stimulate discussion and critical comment. References in publications to International Finance Discussion Papers (other than an acknowledgment that the writer has had access to unpublished material) should be cleared with the author or authors. Recent IFDPs are available on the Web at www.federalreserve.gov/pubs/ifdp/. 


\title{
Corporate Governance and the Shareholder Base
}

\author{
Karl V. Lins and Francis E. Warnock*
}

\begin{abstract}
This paper uses a sample of 4,410 firms from 29 countries to investigate the relation between corporate governance and the shareholder base. In contrast to previous work, our results strongly support the notion that poor corporate governance, at both the firm and country level, negatively impacts the willingness of foreign investors to hold a firm's equity. Specifically, we find that firms whose managers have sufficiently high control rights that they may reasonably be expected to expropriate minority equity investors attract significantly less U.S. investment, especially in countries with poor external governance. Our findings suggest that the prices U.S. investors are asked to pay for firms with poor governance are not low enough to fully compensate them for expected expropriation or increased estimation risk associated with expected poor disclosure by these firms. Because prior research shows that a smaller shareholder base is associated with a lower firm value, our results are consistent with the notion that the shareholder base represents an important channel through which poor expected corporate governance contributes to a reduction in firm value.
\end{abstract}

Keywords: corporate governance, ownership structure, shareholder base, portfolio holdings JEL Classification: G11, G15, G32

\footnotetext{
* Lins is Thayne Robson Scholar and Assistant Professor of Finance at the David Eccles School of Business, University of Utah. Warnock is Economist in the Division of International Finance, Board of Governors of the Federal Reserve System, and Visiting Associate Professor of Business Administration at the Darden Graduate School of Business Administration, University of Virginia. We thank Jillian Faucette, Sara Holland, and Ivalina Kalcheva for valuable research assistance and Anup Agrawal, Alexander Dyck, Dale Henderson, Mike Lemmon, Christian Leuz, Darius Miller, René Stulz, Luigi Zingales, and participants at the NYSE Conference on Global Equity Markets and the Tenth Annual Assurant/Georgia Tech International Finance Conference for helpful comments. We also thank Stijn Claessens, Mara Faccio, and Larry Lang for access to ownership structure data for Japan and Western Europe. The views in this paper are solely the responsibility of the authors and should not be interpreted as reflecting the views of the Board of Governors of the Federal Reserve System or of any other person associated with the Federal Reserve System. The statistical analysis of security-level data on U.S. investors' holdings reported in this study was conducted at the International Finance Division of the Board of Governors of the Federal Reserve System under arrangements that maintained legal confidentiality requirements. Email addresses for the authors are finkvl@business.utah.edu and frank.warnock@frb.gov
} 


\section{Introduction}

This paper uses a sample of 4,410 firms from 29 countries to investigate whether outside investors, particularly sophisticated and deep-pocketed ones, systematically underweight stocks expected to have firm-level and country-level corporate governance problems. In so doing, we aim to improve our understanding of both the valuation impact of expected corporate governance practices and of the difficult to explain home bias in international equity portfolios. From a valuation perspective, research has shown that large private benefits of control, or poor countrylevel shareholder protection, or both, are associated with lower firm values. Additional research in this area indicates that poor corporate governance is correlated with less transparency, which can negatively impact firm value because it increases outside investors' estimation risk. From a home bias perspective, researchers have generally found that, after controlling for the aggregate available free float of a firm's shares, foreign investment does not depend on country-level governance parameters.

Our investigation of corporate governance and the shareholder base is unique because we combine data on a large number of firms that have wide variation in both firm- and country-level governance parameters with a comprehensive dataset on the outside holdings of these firms. We use these data to test two hypotheses that naturally emerge from the existing evidence. Under the null that corporate governance expectations are priced properly, one would not expect the holdings of sophisticated outside investors to depend upon whether firm-level control structures and country-level shareholder protections indicate potentially extreme managerial agency problems. Investors would simply pay lower prices (i.e., demand higher returns) for badly governed firms. Under the alternative, if a large group of outside investors believe that the share prices they are asked to pay for firms with poor firm- and country-level governance do not fully 
reflect the expected expropriation of minority investors, the increased estimation risk of cash flows due to expected poor disclosure, or some other factor associated with poor governance, then one would expect these investors to hold less of such firms. Because a smaller shareholder base has been shown to lessen firm value, such a finding could be interpreted as evidence that a reduced shareholder base is an important mechanism by which poor corporate governance is translated into lower firm values. ${ }^{1}$

For our tests, we proxy for a large pool of sophisticated outside investment capital using the Ammer, Holland, Smith, and Warnock (2004) (hereafter AHSW) dataset, which amalgamates security-level data on all U.S. investors' positions in non-U.S. equities from the 1997 U.S. Treasury and Federal Reserve Board benchmark survey. In using these holdings data, we are implicitly assuming that non-U.S. firms with greater U.S. ownership have broader shareholder bases. For firm-level governance, we use the Claessens, Djankov, and Lang (2000) (Japan), Faccio and Lang (2002) (Western Europe), and Lins (2003) (emerging markets) datasets to construct both nominal and relative proxies indicating that managers and their families are, in effect, in full control of a firm. Our implicit assumption is that the capability to expropriate outside shareholders will be higher when managers' control of a firm cannot be challenged internally. ${ }^{2}$ We proxy for external country-level corporate governance using several shareholder protection measures presented in La Porta, Lopez-de-Silanes, and Shleifer (2004), since managers will have fewer constraints on taking self-interested actions when external countrylevel governance is also weak.

\footnotetext{
${ }^{1}$ Institutional investors frequently express concerns that poor corporate governance limits their willingness to invest. For instance, the long-time manager of the \$1.2 billion Templeton Developing Markets Trust, Mark Mobius, states that "corporate governance is not improving, so why fight it?" [Karmin (2000)]. Similarly, a July 2002 McKinsey and Company survey of global investor opinions reports that "more than $60 \%$ of investors state that governance considerations might lead them to avoid individual companies with poor governance."
} 
Our tests provide compelling evidence that, as a percentage of the available free float, U.S. investors underweight firms with a combination of poor expected firm-level and countrylevel corporate governance. Subsequent tests indicate that it is precisely the combination of poor firm- and country-level governance that matters: we find a relatively weak relation between U.S. investment and firm-level governance when we do not account for country-level governance.

Our findings suggest that the prices U.S. investors are asked to pay for firms with poor expected governance are not low enough to fully compensate them for either expected expropriation or the increased estimation risk associated with expected poor disclosure by these firms. Given the previously identified positive relation between a firm's value and its shareholder base, our results are consistent with the notion that a reduction in the shareholder base represents an important channel through which poor expected corporate governance contributes to a reduction in firm value. Another inference that can be drawn from our findings is that the home bias can be at least partially explained by sophisticated foreign investors' aversion to firms with expected corporate governance problems.

The rest of the paper is organized as follows. Section 2 discusses the literature on international corporate governance and portfolio holdings and motivates the hypotheses that we test. Section 3 describes our data and sample selection. Section 4 describes the empirical analyses used in the paper and contains the results of these analyses. Section 5 concludes.

\section{Extant Literature and Hypotheses}

Corporate governance mechanisms can generally be classified into two interrelated categories. The first is firm-specific internal mechanisms, such as a firm's ownership and

\footnotetext{
${ }^{2}$ As we discuss later in the paper, differences in the categorization of cash flow rights held by managers and families across the three datasets preclude us from obtaining a consistent measure of managerial cash flow rights, which is
} 
control structure. Jensen and Meckling's (1976) agency theory states that when controlling managers have less than full cash flow ownership stakes in their firm, there will be an inherent conflict between these managers and their outside investors. Stulz (1988) points out that this problem will be particularly acute as managers obtain effective control of a firm. The second governance category is country-specific external mechanisms, such as outside shareholder rights, the rule of law, and the market for corporate control. Absent these external protection mechanisms, outside investors will find it difficult to safeguard against managerial expropriation of their interests.

Recent governance research documents that both internal and external corporate governance mechanisms are often weak in international environments and that this adversely affects firm values. ${ }^{3}$ Specifically, countries with few shareholder rights and a weak rule of law tend to have publicly traded companies in which control is highly concentrated and control rights often exceed proportional cash flow ownership [La Porta, Lopez-de-Silanes, and Shleifer (1999)]. There are two ways in which such poor firm- and country-level governance can be expected to adversely affect firm value. First, it portends extreme expected managerial agency problems, so, not surprisingly, the shares of such firms tend to be discounted by outside investors [Claessens, Djankov, Fan, and Lang (2002), Lins (2003), Lemmon and Lins (2003), Dyck and Zingales (2004), Nenova (2003), and Doidge (2004)]. Second, poor corporate governance is also associated with less transparency, as international research documents that poor expected firmlevel governance (Fan and Wong (2002) and Leuz and Oberholzer-Gee (2003)) or poor expected country-level governance (Leuz, Nanda, and Wysocki (2003)), or both (Lang, Lins, and Miller (2004)), have negative implications for a firm's information environment. This, too, can

often used to proxy for incentive alignment between managers and outside shareholders. 
adversely impact firm value; Barry and Brown (1985) show that less information available to outside investors increases their estimation risk of a firm's earnings, which raises their required return for investing in the firm.

Each of these routes through which poor corporate governance is likely to affect firm value may well occur through one mechanism: a restricted shareholder base. Shleifer and Vishny (1986) and Merton (1987), among others, show that a smaller shareholder base is associated with lower firm values. Our aim is to test whether a link between corporate governance and the shareholder base exists. Specifically, do sophisticated outside investors with large amounts of capital to deploy systematically underweight stocks expected to have firm- and country-level governance problems?

We put forth two hypotheses relating outside investors and expected corporate governance. The null is that corporate governance expectations are priced properly for all investors, implying that the holdings of sophisticated outside investors should not depend upon whether firm-level control structures and country-level shareholder protections indicate potentially extreme managerial agency problems. All outside investors would simply pay less for badly governed firms. Alternatively, if a large group of outside investors believe that the share prices they are asked to pay for badly governed firms do not fully reflect the expected expropriation of minority investors, the increased estimation risk of cash flows due to poor transparency, or some other factor associated with poor corporate governance, then one would expect these investors to hold less of such firms. ${ }^{4}$ One could interpret a finding in favor of the

\footnotetext{
${ }^{3}$ See Claessens and Fan (2002) and Denis and McConnell (2003) for recent surveys on the international corporate governance literature.

${ }^{4}$ In the U.S., Gompers, Ishii, and Metrick (2003) also find that firms with poor firm-level governance earn lower returns and have lower firm values. McConnell and Servaes (1990) and McConnell, Servaes, and Lins (2004) provide evidence suggesting that for U.S. firms managerial ownership may mitigate agency problems up to a point, but high levels of control rights may exacerbate agency issues as managers are no longer accountable to minority shareholders.
} 
alternative hypothesis as evidence that a reduced shareholder base may at least partially account for the value reduction associated with poor corporate governance.

Because our proxy for the shareholder base is the holdings of U.S. investors, our work also has implications for the research on international portfolio allocation. Such research on the shareholder base of firms has uncovered a home bias in which investors hold proportionally more domestic equity instead of investing fully in the available world market portfolio. ${ }^{5}$ While some of the literature has found a link between proxies for a firm's information environment (such as firm size or an international cross-listing) and its shareholder base (e.g., Kang and Stulz (1997), Dahlquist and Robertsson (2001), Coval and Moskowitz (1999), AHSW, and Edison and Warnock (2004)), assessments of the relationship between governance and the shareholder base have been limited in scope.

Country-level studies of corporate governance and the shareholder base document several findings. First, countries with weak external governance structures have poor equity market development, presumably because the fear of expropriation deters outside investors, be they domestic or foreign [LLSV (1997) and Giannetti and Koskinen (2004)]. Second, countries with weak external governance structures and a greater proportion of shares held by insiders have fewer shares available to foreign investors [Dahlquist, Pinkowitz, Stulz, and Williamson (hereafter DPSW) (2003)]. Third, after controlling for this reduction in float (the available freely traded shares), there is no evidence that international investors shun countries with poorer governance (DPSW); that is, if portfolio allocations are analyzed relative to the float, extant

\footnotetext{
${ }^{5}$ See Lewis (1999) and Karolyi and Stulz (2002) for surveys of the home bias literature.
} 
evidence does not indicate that poor governance reduces a country's ability to attract international investors. $^{6}$

While extant country-level regressions provide little evidence of a link between governance and the shareholder base once supply effects are controlled for, it could be the case that sophisticated investors overweight strong expected governance firms (such as those with U.S. cross listings) and underweight weak expected governance firms. Thus, a more thorough understanding of corporate governance and the shareholder base calls for firm-level tests. To our knowledge, firm-level evidence is limited to conflicting results from one country: Sweden. DPSW and Giannetti and Simonov (2003) both examine Swedish equities; the former finds no evidence that poor firm-level corporate governance deters foreign investors, whereas the latter, analyzing a zero-one indicator variable for the existence of foreign investment, concludes that foreign investors avoid Swedish firms with poor corporate governance.

The overall lack of consistent evidence demonstrating a link between corporate governance and the shareholder base could owe to several reasons. First, it could be a manifestation of the null hypothesis that poor expected governance is properly priced and, hence, does not deter investors. Second, it could be that the blunt country-level governance measures used in previous work are too coarse to pick up the effect. Finally, it could be that the firm-level studies of DPSW and Giannetti and Simonov (2003) examined the equities of a country with strong governance (Sweden), and such external governance lessens the expected impact of potential firm-level governance problems. To the extent that corporate governance impacts the shareholder base, but has not been shown to do so empirically, the wide variation in both firm-

\footnotetext{
6 Specifically, DPSW state that '...for a given supply of shares, U.S. investors do not invest less in a country because minority shareholders are less well protected or because laws are not enforced' (DPSW, page 104). Contemporaneous work by Giannetti and Koskinen (2004) provides evidence that better-governed countries, which have larger equity markets, have greater weights in a sample of institutional investors' portfolios.
} 
and country-level expected governance contained in our sample could allow us to uncover this relation.

International cross-listings represent a special case. Studies have found that cross-listings result in an expanded shareholder base [Ahearne, Griever, and Warnock (2004), AHSW, Edison and Warnock (2004)] and that cross-listed firms experience an increase in value [Foerster and Karolyi (1999) and Miller (1999)]. Because these studies focus on non-U.S. firms that cross-list

on a U.S. exchange, the cross-listing can be interpreted as an improvement in the governance and information environments [Lang, Lins, and Miller (2003) and Doidge, Karolyi, and Stulz (2004)]. Hence, the cross-listing literature provides evidence that improved governance or information, or both, is associated with an enhanced shareholder base. ${ }^{7}$ However, the vast majority of non-U.S. firms are not cross-listed; in 1997, only about 400 of the more than 10,000 publicly traded non-U.S. firms were listed on U.S. exchanges. For the more than 95 percent of non-U.S. firms not cross-listed, does governance affect the shareholder base?

\section{Sample Selection and Variable Construction}

In this section, we describe our sample selection process and our proxies for expected corporate governance at both the firm- and country-level. We then proceed with a description of our proxy for the shareholder base: the proportion of shares held by U.S. investors.

\subsection{Firm-level Corporate Governance}

To examine whether U.S. investment is related to firm-level corporate governance, we obtain ownership and control structure data for Western European firms from Faccio and Lang 
(2002); for emerging market firms from Lins (2003); and for Japan from Claessens, Djankov, and Lang (2000). Ownership and control data for Japanese and emerging market firms are from the 1995/1996 period and those from Western Europe range from 1996 to 1999 , with the majority of sample observations occurring in 1996. We confine our analysis to non-financial firms to maintain consistency across the three ownership and control structure datasets. Claessens, Djankov and Lang (2000), Faccio and Lang (2002), and Lins (2003) all report ownership and control statistics that could proxy for a firm's internal corporate governance environment. For instance, the percentage of total ultimate control rights held by the following types of blockholders are reported: Family/Management, Government, Widely-Held Corporations, Widely-Held Financials, and Miscellaneous (which includes ownership by Trusts, Cooperatives, Foundations, Employees, etc.).

To measure firm-level governance, we focus in particular on management and family control rights, since it is the management group (and their families) that actually makes the operational and financial decisions of a firm. We seek to construct measures that indicate that a firm's managers are, in effect, in full control of a firm because, all else equal, the capability to expropriate minority shareholders will be highest when managers' control of a firm cannot be challenged internally.

Because effective managerial control depends on the control rights held by management as well as the control rights held by outside blockholders, we use both nominal and relative measures of effective managerial control in our analysis. The nominal one is the percentage of control rights held by the management group and its family, with the idea that higher levels of managerial control correspond to more effective control of a firm. The relative measures

\footnotetext{
${ }^{7}$ Indeed, an effort to enhance the shareholder base is often cited as an explanation for why non-U.S. firms undertake costly information-providing efforts such as listing on U.S. stock exchanges [Reese and Weisbach (2002) and Lins,
} 
correspond to the idea that high raw levels of control may not always be necessary to establish effective managerial control; rather, managers need only to obtain sufficient control rights such that they can avoid being influenced by other blockholders. Our three relative measures of effective managerial control consist of indicator variables set equal to one when Family/Management control rights exceed: 1) the median level of Family/Management control rights of all sample firms in the country; 2) the median level of Family/Management control rights of all sample firms in the country as well as the control rights held by any other blockholder in the firm; or 3) $50 \%$ of the total outstanding shares of a firm. Of these relative measures, the $50 \%$ control threshold is the strongest measure of effective managerial control. In our models, we also directly test the importance of non-management blockholdings by using the percentage of control rights and an indicator variable for non-management control above $50 \%$.

We acknowledge that our measures focus only on the capability for expropriation and not on the incentives to avoid expropriation. To measure incentives, we would need to know the ultimate cash flow ownership stakes held by the management group and its family for all of our firms. Unfortunately, the cash flow ownership data presented in Faccio and Lang (2002), Lins (2003), and Claessens, Djankov and Lang (2000) are categorized using different algorithms, which makes it difficult to construct a consistent measure for our analysis. Faccio and Lang and Claessens et al. report the separation of ownership and control for the largest blockholder of their sample firms (which may not be the Family/Management group), while Lins reports this measure for all holdings of the Family/Management group (which may not be the largest blockholder). Given these difficulties, we focus our firm-level governance analysis on the control rights held

Strickland, and Zenner (2004)]. 
by the management group and its family since this measure can be consistently identified for all sample countries. ${ }^{8}$

While Claessens, Djankov, Fan, and Lang (2002) show that, in East Asia, a difference between the largest shareholder's control rights and cash flow rights is negatively related to firm value, our inability to conduct tests on managerial control rights that also incorporate managerial cash flow rights may not be crucial to our inferences. To the extent that effective managerial control can be established at some level below 100\%, control and cash flow rights will be inherently separated. Generally, managerial control of $51 \%$ of the shares will confer unequivocal control rights. In such a case, controlling managers that divert one dollar from the firm for personal gain will bear at most 51 cents of the cost. Any further separation of control from cash flow rights via pyramids and superior voting shares may be of a second order effect. ${ }^{9}$

\subsection{Country-level Corporate Governance}

Since there is not a clear criterion for establishing that a country offers poor investor protection, we employ several of the criteria most frequently used in the international stock market development and corporate governance literature. First, we classify non-English legal origin countries as low protection because LLSV $(1997,1998)$ suggest that countries with a traditional English legal origin tend to provide stronger investor protections. Second, La Porta,

\footnotetext{
${ }^{8}$ As mentioned, we focus on control rights because our interest is in whether minority investors respond to concerns about governance problems created by concentrated managerial control. While we do not have data to separate the effect of managerial cash flow rights from control rights, the analysis in Faccio and Lang (2002) and Lins (2003) suggests that, for our sample, ultimate managerial control rights often exceed cash flow rights because of pyramid ownership structures and superior voting shares.

${ }^{9}$ In untabulated tests, we obtain data on the ratio of control rights to cash flow rights for the largest blockholder from Faccio and Lang (Western Europe) and Claessens et al. (East Asia) and use it as an alternate firm level corporate governance proxy. This variable is generally insignificant in our models. We presume the lack of significance obtains because either this separation is a second order effect or because Table 1 (discussed in the next section) shows that managers and their families are the largest blockholder for $53 \%$ of the firms, so this variable does not contain information about management/family control and cash flow rights for almost half (47\%) of our sample.
} 
Lopez-de-Silanes, and Shleifer (2004) find that a Disclosure Rights Index and a Liability Standards Index, often together referred to as a Private Enforcement measure, are among the most important determinants of investors' participation in a country's stock markets. Therefore, we differentiate between low and high protection countries based on whether the average of these two indices is below or above our sample average of 0.60 . Finally, we use the categorization scheme for Antidirector Rights in LLSV (1998) and classify countries with Antidirector Rights below 4 as low protection countries and those with scores equal to or above 4 as high protection countries.

\subsection{A Firm-Level Measure of the Shareholder Base}

The shareholder base is a loosely defined concept that defies easy measurement, particularly since we study non-U.S. firms which rarely have to identify the full breadth of their shareholders. In the theoretical model of Merton (1987), the shareholder base is related to the percentage of outside investors who know about the firm. In the Foerster and Karolyi (1999) empirical study of 153 non-U.S. firms subject to U.S. listing requirements, the shareholder base is proxied by the number of registered shareholders. Because information on registered shareholders is not available for our sample of over 4000 firms, we use a mandatory and confidential survey conducted by the U.S. Treasury Department and the Federal Reserve Board ${ }^{10}$ of the holdings of all U.S. investors as of December 1997 to obtain our proxy for a firm's shareholder base: the percentage of a firm's free float that is held by U.S. investors. The typical U.S. investor who ventures abroad is an institution, but our data include foreign equity holdings

\footnotetext{
${ }^{10}$ For a primer on the surveys, see Griever, Lee, and Warnock (2001). Publicly available country-level dataformed by aggregating the confidential security-level data used here - have been analyzed in Ahearne, Griever, and Warnock (2004) and DPSW. The security-level data have been studied by AHSW (2004) and, using a much more limited sample, Edison and Warnock (2004).
} 
by all types of U.S. investors, who collectively hold $47 \%$ of the world's international equity positions. ${ }^{11}$ In our view, a firm's shareholder base is broader if a greater proportion of its outstanding shares are held by this large and sophisticated group of outside investors. If this assumption is reasonable, then so is our proxy.

We note that our data on the security-level equity positions of foreign investors are much more extensive than any other currently available. For example, the holdings data used in Bradshaw, Bushee, and Miller (2004), comprised of SEC data that should only include holdings of securities traded in the United States, show positive holdings by U.S. institutional investors in only $5 \%$ of foreign firms. Our data set, which includes holdings of all foreign securities regardless of whether they trade in the United States, reports positive holdings by U.S. investors for more than $75 \%$ of our 4410 firms. ${ }^{12}$

\subsection{Sample Selection and Summary Statistics}

We combine the firm-level control structure data presented in Faccio and Lang (2002), Lins (2003), and Claessens, Djankov and Lang (2000) resulting in 6974 firms. We exclude 976 financial firms. We obtain financial variable data (used as controls in regressions) and float data from the Worldscope database for the year-end closest to December 31, 1997 since our U.S. holdings data are from that point in time and it closely corresponds to the date of our ownership and control data; these data are not available for 1582 firms. ${ }^{13}$ Finally, we exclude six firms that appear to have bad market capitalization and float data. Our final sample consists of 4410 firms.

\footnotetext{
${ }^{11}$ Of the $\$ 2.6$ trillion in international equity positions reported to the IMF-led 1997 Coordinated Portfolio Investment Survey, U.S. investors held $\$ 1.2$ trillion.

12 The Bradshaw et al. holdings dataset has poorer coverage for foreign firms because non-U.S. securities are reportable on 13(f) filings only if they are publicly traded in U.S. markets. That is, 13(f) filings should include U.S. institutions' holdings of ADRs, but not holdings of the underlying foreign security or non-ADRs.

13 When calculating a firm's float, we correct the closely-held variable by subtracting the amount that Worldscope erroneously attributes to depository banks; see AHSW.
} 
Table 1 provides summary statistics for our sample based on a firm's country of domicile. Our sample, which includes firms from 29 countries, is concentrated in Europe (2468 firms) and Asia (979 Japanese firms and another 800 from Emerging Asia), with relatively few (61) Latin American firms.

The second and third columns of Table 1 present mean levels of U.S. investment as a percent of float and of market capitalization (which we use in robustness tests). In our sample, U.S. investors hold on average $6.4 \%$ of the available float and $3.6 \%$ of the total market capitalization. U.S. ownership is highest in Latin America, particularly Argentina, and lowest in Asia. The fourth column of Table 1 shows that our firms are quite large overall, with mean assets of 1.75 billion U.S. dollars.

Columns 5 through 8 detail blockholder statistics for our sample. For the median firm, Family/Management group control is $13 \%$, with wide variation across countries. The median of the control rights held by blockholders other than the Family/Management group is 5\%, with a similarly wide variation in this parameter across countries. The table shows that the Family/Management group is by far the dominant type of controlling blockholder. Family/Management group control rights exceed those of any other blockholder for $53 \%$ of the sample ${ }^{14}$ and exceed $50 \%$ of total control rights in $22 \%$ of sample firms.

\section{Empirical Tests and Results}

\subsection{Construction of the Empirical Model}

Firms with substantial insider holdings will almost surely have narrower shareholder bases, as fewer shares are available to outside investors. We are interested in assessing whether

\footnotetext{
${ }^{14}$ For 127 firms, we are unable to unambiguously identify the largest blockholder, so these firms are dropped from tests using this indicator variable.
} 
there is an additional effect of corporate governance on the shareholder base above and beyond this supply effect. That is, we exclude shares tied up by insiders and other large blockholders and define our proxy for the shareholder base as the proportion of firm $i$ 's float that is held by U.S. investors:

USInvestme nt $i \equiv \frac{\text { USHoldings }_{i}}{\text { Float }_{i}}$

While it is crucial to account for a firm's float in our shareholder base tests, scaling by float will mechanically bias our results against finding a significant negative relation between Family/Management control and U.S. investment. This occurs because an increase in Family/Management control will reduce the available float. If U.S. investment does not change, U.S. investment as a percentage of float will nonetheless increase. Thus, to the extent we find that Family/Management control is negatively related to U.S. ownership as a share of float, the inference that poor expected governance negatively impacts the shareholder base-above and beyond the direct effect through limiting the float—will be particularly robust.

In our analysis, the primary variables of interest are the control structure variables that proxy for expected firm-level corporate governance. Before directly assessing these variables, it is important to control for a firm's size, leverage, growth prospects, and international presence, because researchers have found these factors to be related to portfolio investment levels. Kang and Stulz (1997) and Dahlquist and Robertsson (2001) document that foreign investors in Japan and Sweden avoid small, highly levered stocks that do not have an international presence, possibly because information about them is less readily available. Consistent with this 
interpretation, Coval and Moskowitz (1999) find that the local bias is greater for such firms. Foreign investors in Japanese and Swedish equities also show a preference for growth stocks.

To control for firm size we use Size, calculated as the log of total assets converted to thousands of U.S. dollars. We control for Leverage using the ratio of total debt to total assets. Firms with higher leverage are more financially vulnerable and, thus, might attract less outside investment. Additionally, Harvey, Lins, and Roper (2004) find that leverage can mitigate the value loss associated with extreme expected managerial agency problems. We include a crosslisting dummy variable, XLIST, that takes the value of one if the firm is listed on a U.S. exchange as a proxy for both an international presence and a lessening of direct and indirect barriers to international investment. ${ }^{15}$ Edison and Warnock (2004) and AHSW (2004) find cross listing to be associated with a substantial increase in the U.S. shareholder base. ${ }^{16}$

We include two proxies for growth in our models. Book-to-market, calculated as the book value per share over the year-end market price, is included because a preference for growth stocks can be reflected in a tendency to hold low book-to-market value stocks. Dividend Yield, calculated as dividends per share over the year-end market price, could be related to growth if firms with better growth prospects pay lower dividends as they plow revenues back into the firm. If U.S. investors prefer growth stocks and these two measures capture growth opportunities, we would expect to see a negative relation between each measure and U.S. holdings. However, low dividend payments by non-U.S. firms could also represent expected firm-level governance problems (LLSV (2000) and Kalcheva and Lins (2004)) in which case dividend yields could be positively related to U.S. holdings if U.S. investors seek to avoid firms with poor expected

\footnotetext{
${ }^{15}$ A firm's foreign sales, another measure of international presence, has poor coverage in Worldscope, so we follow Dahlquist and Robertsson (2001) and utilize a cross-listing variable instead.

16 Aggarwal, Klapper, and Wysocki (2003) - in explaining mutual fund investment in emerging market firms that are in the MSCI index - also find a positive cross-listing effect.
} 
governance. Finally, because investors often favor certain industries or countries, we include controls for both in our models.

Although more than $75 \%$ of the firms in our sample are held by U.S. investors, the nontrivial number of firms with zero U.S. holdings prompts us to utilize a Tobit regression model. Specifically, we estimate Tobit regression models of the following form:

$$
\begin{aligned}
\text { U.S. investment } & =\beta_{0}+\beta_{1} \text { Managerial and Family Control }+\beta_{2} \text { XLIST }+\beta_{3} \text { Firm Size } \\
& +\beta_{4} \text { Leverage }+\beta_{5} \text { Book to Market }+\beta_{6} \text { Dividend Yield } \\
& +\beta_{7} \text { Country Controls }+\beta_{8} \text { Industry Controls }
\end{aligned}
$$

where:

U.S. investment $=$ U.S. holdings as a percentage of available float.

Control structure variables $=$ Family $/$ Management control rights percentage; an indicator variable set equal to one if the Family/Management group's control rights are greater than the median value of the control rights held by the Family/Management group for all firms in its country; an indicator variable set equal to one if the Family/Management group's control rights are greater than the median country value and the Family/Management group is the largest blockholder of control rights; or an indicator variable set equal to one if Family/Management has majority (i.e., $>50 \%$ ) control rights. For comparison purposes, we also use the percentage of control rights held by Other (i.e., non-Family/Management) blockholders or an indicator that Other blockholder control rights exceed $50 \%$.

XLIST $=$ An indicator variable that takes on the value one if the firm's equity is listed on a U.S exchange either directly or as a Level II or Level III ADR.

Firm size $=$ The log of total assets measured in thousands of U.S. dollars.

Leverage $=$ The ratio of total debt to total assets. 
Book to Market $=$ The book value per share over the fiscal year-end market price.

Dividend Yield $=$ Dividends per share over the fiscal year-end market price.

Industry Controls = Industry indicator variables as classified by Campbell (1996).

Country Controls $=$ Indicator variables based on a firm's country of domicile.

\subsection{Incorporating Country-Level Governance}

To fully test the alternative hypothesis that sophisticated investors hold relatively less of firms with poor expected governance, we need to also incorporate country-level governance into our analysis. To the extent that firm-level governance matters for the shareholder base, it is likely to matter more where outside investor protection is weak because managers are more easily able to expropriate minority investors in such a setting. However, even in countries with strong investor protection, we might expect to see concentrated Family/Management control associated with reduced U.S. investment because firms have significant discretion on issues such as voluntary disclosure.

Our basic tobit regression model features firm-level governance proxies along with country (fixed effects) controls. To ascertain whether poor governance at both the firm and country level is related to U.S. investment, we estimate our models within low and high protection subsamples based on our three previously described measures of a country's investor protection: Legal Origin, Private Enforcement, and Antidirector Rights.

\subsection{Low and High Protection Subsample Results}

Table 2 presents the association between our firm-level governance proxies and U.S. investment by legal origin. Panel A reports results for our low protection subsample: those 
countries with non-English legal systems. ${ }^{17}$ Model 1 tests our nominal measure of effective managerial control. This model shows that after controlling for other factors, an increase in the control rights held by the Family/Management group corresponds to a decrease in U.S. investment. The $25^{\text {th }}$ percentile for Family/Management control in this subsample is zero and the $75^{\text {th }}$ percentile is $49 \%$. The coefficient of -0.0429 indicates that, all else equal, a firm in a low shareholder rights country for which Family/Management control changes from the $25^{\text {th }}$ to the $75^{\text {th }}$ percentile would have U.S. investment (as a share of float) that is 2.1 percentage points lower, an economically significant amount given that average U.S. investment is $6.4 \%$. Results for the second, third, and fourth models — which use relative measures of Family/Management control—are similar. For example, Model 4 shows that majority Family/Management control rights are associated with a 2.5 percentage point reduction in U.S. investment. Overall, the significant results for all four measures of Family/Management control indicate support for the hypothesis that effective managerial control dissuades equity investment by U.S. investors.

The fifth and sixth models show that the control held by all blockholder types other than the Family/Management group is not significantly related to U.S. investment. This lack of significance is not particularly surprising since, as mentioned previously, this category includes a wide range of blockholders and there is less of a reason to expect that these outside blockholders have the ability to consume significant private benefits of control or to distort information flows.

Panel B reports on the English legal origin sample, which corresponds to high countrylevel shareholder protection. We observe that none of the blockholder coefficients are negative and significant. One coefficient is positive and marginally significant, but given the

\footnotetext{
${ }^{17}$ In all six models, the variables that control for other factors have the expected signs and are generally significant. U.S. investment is positively related to float and negatively related to leverage, consistent with the findings of Kang and Stulz (1997) and Dahlquist and Robertsson (2001). As in Edison and Warnock (2004) and AHSW (2004), firms that are cross-listed on a U.S. exchange have greater U.S. investment, about 7 percentage points more in this sample.
} 
mechanically induced positive bias from our float-normalized dependent variable, it is not appropriate to read much into this finding. More important is the comparison between between the blockholder coefficients in the low and high protection subsamples, shown in the bottom row of Panel B. We find that all four of the managerial control coefficients are significantly more negative in the low protection subsample $(p$-values $<0.01) .{ }^{18}$ These results indicate that, while the prices that U.S. investors are asked to pay for firms with poor governance may be low, they apparently are not low enough on average to compensate for expected expropriation or estimation risk.

In Table 3, we split the sample based on the Private Enforcement measure of shareholder protection. Panel A again shows that the coefficients on our one nominal and three relative measures of Family/Management control are always negative and highly significant in the low protection subsample. The coefficients on other blockholdings are insignificant. Also, we again find that the difference in the four effective managerial control coefficients between the low and high protection subsamples is always highly significant.

In Table 4, we split the sample based on a country's Antidirector Rights. As in the previous tables, the coefficients on the effective managerial control measures are all negative and highly significant in the low shareholder protection subsample (Panel A), insignificant in the high protection subsample (Panel B), and the coefficient differences between the subsamples are highly significant.

Overall, the evidence in this section is consistent with the idea that foreign investors choose to hold less equity in firms that can be expected to have particularly acute corporate

Book-to-market is negative and highly significant, indicating that, all else equal, U.S. investors favor growth firms. Dividend yield is consistently negative but never significant.

${ }^{18}$ The significance level is based on (untabulated) combined regressions in which all variables are interacted with an indicator variable set equal to one when a country belongs to the low protection subsample. 
governance problems due to the combination of unchallenged managerial control and limited external investor protection. Since previous work has found little, if any, evidence of a relation between expected corporate governance and portfolio holdings, our results also indicate that it is important to consider both firm-level and country-level governance in tandem. Further, because we measure U.S. investment as a percent of the available float, in our view these results provide clear evidence that poor firm level governance limits foreign investment above and beyond the direct effect through limiting the float.

\subsection{Full Sample of Countries}

For completeness, we also estimate our regressions over the full sample of countries without explicitly segmenting based on the country-level investor protection environment (although we continue to include country fixed effects). The results, shown in Table 5, highlight the importance of considering the external investor protection environment. When mixing all types of countries, the coefficient on the Family/Management group control variables are generally smaller in magnitude, or less significant, or both. Model 1 shows that an increase in the control rights held by the Family/Management group corresponds to a decrease in U.S. investment, but the implied decrease is less than in the low protection sub-samples of the previous tables. Results for the second, third, and fourth models are similarly less strong, and the relative measures of effective managerial control tested in Models 2 and 3 are marginally insignificant. The fifth and sixth models show that the control held by all blockholder types other than the Family/Management group is not significantly related to U.S. investment. 


\subsection{The Relation between U.S. Investment Scaled by Market Capitalization and Governance}

In Tables 2 through 5 we measured U.S. investment as a percentage of the available float, which had a built in bias against finding a negative relation between a firm's blockholdings and its outside investor holdings. As a robustness check, in Tables 6 and 7 we alleviate this bias by scaling U.S. investment by total equity market capitalization:

USInvestme t $_{i} \equiv \frac{\text { USHoldings }_{i}}{\text { MarketCapi talization }_{i}}$

When we use this alternative measure of U.S. investment, we control for float by including our float measure as an explanatory variable. Table 6 reports on these tests of U.S. investment scaled by market capitalization for the full sample of countries. ${ }^{19}$ The first model again shows that, putting aside the shares tied up by blockholders, U.S. investors hold less of the remaining shares when the percentage of Family/Management control is greater. Using this alternate U.S. investment measure, Models 2 through 4 now show that the three relative measures of effective Family/Management control are all significant and have the expected negative sign. Models 5 and 6 again indicate that the extent of other blockholders' control is not important.

In Table 7 , we conduct investor protection sample splits, similar to Tables $2-4$, but report only the blockholder variable of interest for the sake of brevity. Throughout this table, we find results identical to those found previously using U.S. holdings normalized by float. In the low protection subsamples, all measures of effective managerial control are negative and highly

\footnotetext{
19 In Tables 6 and 7, the results for variables that control for other factors are as in Tables 2-5 with one exception: book-to-market becomes positive and significant when holdings are scaled by market capitalization. We offer no explanation for this difference, but do note that all of our results hold if book-to-market is omitted from the study.
} 
significant, and the difference in the coefficients between low and high protection subsamples is always significant as well.

Overall, the evidence in Tables 6 and 7 is consistent with the idea that expected firmlevel governance problems limit U.S. investors' willingness to hold firms and, as in the previous subsection, the negative effect of concentrated managerial control on U.S. investment is significantly more pronounced in cases in which there is weak investor protection.

\subsection{Further Robustness Checks}

In this section, we discuss further tests of robustness, which are not tabulated for sake of brevity. For instance, there is a clustering of observations in Japan and the U.K., creating the possibility that the results are dominated by one or two countries. The country dummies included in our analysis allow us to control for unique country parameters, but for robustness we re-estimate our firm-level regressions without Japan, the U.K., or both. For Japan, Lins and Servaes (1999) find that strong keiretsu membership is an indicator of governance problems, whereas ownership structure is not. Claessens, Djankov, Fan, and Lang (2002) exclude Japan from their analysis of ownership structure in East Asia because the keiretsu system influences governance in ways that cannot be captured by ownership data. In our study, removing Japan from the sample has no noticeable effect on our main results. If we remove the U.K., some (but not all) measures of Family/Management control become significant in the high protection subsamples, as poor expected firm-level governance matters somewhat more in non-U.K. high protection countries. Correspondingly, some (but not all) of the differences between the high and low subsamples become less significant when the U.K. is excluded. 
Finally, whether a foreign firm is cross-listed on a U.S. exchange is the single most important determinant of U.S. investment [AHSW (2004)]. To confirm that cross-listed firms are not unduly influencing our results, we re-estimate the firm-level regressions limiting the samples to non-cross-listed firms. Eliminating the 140 cross-listed firms in our sample has no effect on our results.

\section{Conclusion}

This paper examines the relationship between a firm's shareholder base and its corporate governance structure. In contrast to previous work, we find that a firm's corporate governance environment, at both the firm and country level, is directly related to the willingness of a large and sophisticated group of foreign investors to hold its shares. Overall, our findings indicate that firms whose managers have sufficiently high control rights that they may reasonably be expected to expropriate minority equity investors attract significantly less U.S. investment, especially in countries with poor external governance. Our results are consistent with the notion that a reduction in the shareholder base represents an important channel through which poor expected corporate governance contributes to a reduction in firm value. Our findings also suggest that the prices U.S. investors are asked to pay for non-U.S. firms with poor expected governance are not low enough to fully compensate them for expected expropriation or the increased estimation risk associated with expected poor disclosure by these firms.

Our findings also have implications for the nature of global capital flows and international financial integration. Should a country's corporate governance environment and laws change in ways that compel Family/Management groups to unwind some part of their controlling holdings, international integration might increase along several dimensions. First, the 
reduced insider control could be associated with increased participation by foreign investors. Second, LLSV (1997) and Giannetti and Koskinen (2004) argue that improved corporate governance should be associated with improved equity market development as local outsiders increase participation in response to a reduction in disincentives. Finally, international integration could increase once again when these new equity investors diversify internationally.

While we find that U.S. investors are less likely to hold non-U.S. firms that have poor expected governance, we do not attempt to identify the mechanism(s) that give rise to this relationship. The lower holdings could result from improperly priced expropriation risk and the associated expected cash flow reduction. The lower holdings could also stem from increased estimation risk, as information asymmetries are likely exacerbated for such firms. Future research might be able to discern which mechanism is more important and could perhaps uncover other relevant mechanisms. 


\section{References}

Aggarwal, Reena, Leora Klapper, and Peter D. Wysocki, 2003, Portfolio Preferences of Foreign Institutional Investors, mimeo, Georgetown University.

Ammer, John, Sara Holland, David Smith, and Francis E. Warnock, 2004, Look at Me Now: The Role of Cross-Listings in Attracting U.S. Shareholders, International Finance Discussion Paper 815, Board of Governors of the Federal Reserve System.

Ahearne, Alan G., William L. Griever, and Francis E. Warnock, 2004, Information Costs and Home Bias: An Analysis of U.S. Holdings of Foreign Equities, Journal of International Economics 62, 313-336.

Barry, Chris, and Stephen Brown, 1985, Differential Information and Security Market Equilibrium, Journal of Financial and Quantitative Analysis 20, 407-422.

Botosan, Christine, and Marlene Plumlee, 2002, A Re-examination of Disclosure Level and Expected Cost of Equity Capital, Journal of Accounting Research 40, 21-40.

Bradshaw, Mark., Brian Bushee, and Gregory Miller, 2004, Accounting Choices, Home Bias, and U.S. Investment in non-U.S. Firms, forthcoming Journal of Accounting Research.

Campbell, John, 1996, Understanding Risk and Return, Journal of Political Economy 104, 298345.

Claessens, Stijn, Simeon Djankov, and Larry H.P. Lang, 2000, The Separation of Ownership and Control in East Asian Corporations, Journal of Financial Economics 58, 81-112.

Claessens, Stijn, Simeon Djankov, J.P.H. Fan, and Larry H.P. Lang, 2002, Disentangling the Incentive and Entrenchment Effects of Large Shareholdings, Journal of Finance, 57, 2741-2771.

Claessens, Stijn, and Joseph P.H. Fan, 2002, Corporate Governance in Asia: A Survey, International Review of Finance 3, 71-103.

Coval, Josh, and Tobias Moskowitz, 1999, Home Bias at Home: Local Equity Preference in Domestic Portfolios, Journal of Finance 54(6), 1-39.

Dahlquist, Magnus, and Goran Robertsson, 2001, Direct Foreign Ownership, Institutional Investors, and Firm Characteristics, Journal of Financial Economics 59, 413-440.

Dahlquist, Magnus, Pinkowitz, Lee, René Stulz, and Rohan Williamson, 2003, Corporate Governance and the Home Bias, Journal of Financial and Quantitative Analysis, 38, 87110. 
Denis, Diane, and John J. McConnell, 2003, International Corporate Governance, Journal of Financial and Quantitative Analysis 38, 1-36.

Doidge, Craig, 2004, U.S. Cross-listings and the Private Benefits of Control: Evidence from Dual-Class Shares, forthcoming Journal of Financial Economics.

Dyck, A., and L. Zingales, 2004, Private Benefits of Control: An International Comparison, Journal of Finance 59, 537-600.

Edison, Hali J., and Francis E. Warnock, 2004, U.S. Investors' Emerging Market Equity Portfolios: A Security-Level Analysis, Review of Economics and Statistics (June).

Faccio, Mara, and Larry H.P. Lang, 2002, The Ultimate Ownership of Western European Corporations, Journal of Financial Economics, 65, 365-395.

Fan, Joseph P.H., and T.J. Wong, 2002, Corporate Ownership Structure and the Informativeness of Accounting Earnings in East Asia, Journal of Accounting and Economics 33, 401-425.

Foerster, S., and G. Andrew Karolyi, 1999, The Effects of Market Segmentation and Investor Recognition on Asset Prices: Evidence from Foreign Stocks Listing in the U.S., Journal of Finance 54(3).

Giannetti, Mariassunta, and Yrjo Koskinen, 2004, Investor Protection and the Demand for Equity, Stockholm School of Economics Working Paper \# 526.

Giannetti, Mariassunta, and Andrei Simonov, 2003. Which Investors Fear Expropriation? CEPR Working Paper 3843.

Gompers, P, L. Ishii, and A. Metrick, 2003, Corporate Governance and Equity Prices, Quarterly Journal of Economics 118, 107-155.

Griever, William L., Gary A. Lee, and Francis E. Warnock, 2001, The U.S. System for Measuring Cross-Border Investment in Securities: A Primer with a Discussion of Recent Developments, Federal Reserve Bulletin 87(10), 633-650.

Harvey, Campbell R., Karl V. Lins, and Andrew H. Roper, 2004, The Effect of Capital Structure when Expected Agency Costs are Extreme, forthcoming, Journal of Financial Economics.

Jensen, M.C., and W.H. Meckling, 1976, Theory of the Firm: Managerial Behavior, Agency Costs, and Ownership Structure, Journal of Financial Economics 3, 305-360.

Kalcheva, Ivalina, and Karl V. Lins, 2004, International Evidence on Cash Holdings and Expected Managerial Agency Problems, Working Paper, University of Utah. 
Kang, Jun-Koo, and Rene Stulz, 1997, Why is There a Home Bias? An Analysis of Foreign Portfolio Equity Ownership in Japan, Journal of Financial Economics 46, 3-28.

Karmin, Craig, 2000, Corporate Governance Issues Hamper Emerging Markets, Wall Street Journal 8, C1.

Karolyi, G.Andrew, and Rene Stulz, 2002, Are Financial Assets Priced Locally or Globally? NBER Working Paper Number 8994.

La Porta, Rafael, Florencio Lopez-de-Silanes, Andrei Shleifer, and Robert W. Vishny, 1997, Legal Determinants of External Finance, Journal of Finance 52(3), 1131-1150.

La Porta, Rafael, Florencio Lopez-de-Silanes, Andrei Shleifer, and Robert W. Vishny, 1998, Law and Finance, Journal of Political Economy 106, 1113-1155.

La Porta, Rafael, Florencio Lopez-de-Silanes, and Andrei Shleifer, 1999, Corporate Ownership Around the World, Journal of Finance 54, 471-517.

La Porta, Rafael, Florencio Lopez-de-Silanes, and Andrei Shleifer, 2004, What Works in Securities Laws?, Working Paper, Dartmouth College (June version).

La Porta, Rafael, Florencio Lopez-de-Silanes, Andrei Shleifer, and Robert W. Vishny, 2000, Agency Problems and Dividend Policies Around the World, Journal of Finance, Vol. 55, $1-33$.

La Porta, Rafael, Florencio Lopez-de-Silanes, Andrei Shleifer, and Robert W. Vishny, 2002, Investor Protection and Corporate Valuation, Journal of Finance, Vol. 57, No. 3, 11471170.

Lang, Mark H., Karl V. Lins, and Darius P. Miller, 2003, ADRs, Analysts, and Accuracy: Does Cross-Listing in the U.S. Improve a Firm's Information Environment and Increase Market Value? Journal of Accounting Research 41, 317-345.

Lang, Mark H., Karl V. Lins, and Darius P. Miller, 2004, Concentrated Control, Analyst Following and Valuation: Do Analysts Matter Most When Investors are Protected Least?, Journal of Accounting Research 42, 581-623.

Lemmon, Michael L., and Karl V. Lins, 2003, Ownership Structure, Corporate Governance, and Firm Value: Evidence from the East Asian Financial Crisis, Journal of Finance, Vol. 58, 1445-1468.

Leuz, Christian, and Robert Verrecchia, 2000, The Economic Consequences of Increased Disclosure, Journal of Accounting Research 38, 91-124. 
Leuz, Christian, Dhananjay Nanda, and Peter Wysocki, 2003, Investor Protection and Earnings Management: An International Comparison, Journal of Financial Economics 69, 505527.

Leuz, Christian, and Felix Oberholzer-Gee, 2003, Political Relationships, Global Financing, and Corporate Transparency, Working Paper (August), University of Pennsylvania.

Lewis, Karen K., 1999, Trying to Explain the Home Bias in Equities and Consumption. Journal of Economic Literature, 37, 571-608.

Lins, Karl V., 2003, Equity Ownership and Firm Value in Emerging Markets, Journal of Financial and Quantitative Analysis, 38, 159-184.

Lins, Karl, and Henri Servaes, International Evidence on the Value of Corporate Diversification, Journal of Finance 54, 2215-2239.

Lins, Karl V., Deon Strickland, and Marc Zenner, 2004, Do Non-U.S. Firms Issue Equity on U.S. Stock Exchanges to Relax Capital Constraints?, forthcoming, Journal of Financial and Quantitative Analysis.

McConnell, John J., and Henri Servaes, 1990, Additional Evidence on Equity Ownership and Corporate Value, Journal of Financial Economics 27, 595-612.

McConnell, John J., Henri Servaes, and Karl V. Lins, 2004, Changes in Equity Ownership and Changes in the Market Value of the Firm, Working Paper, London Business School.

McKinsey and Company, 2002, Global Investor Opinion Survey, July.

Merton, R., 1987, A Simple Model of Capital Market Equilibrium with Incomplete Information, Journal of Finance 42, 483-510.

Miller, Darius P., 1999, The Market Reaction to International Cross-Listings: Evidence from Depositary Receipts, Journal of Financial Economics 51, 103-123.

Nenova, Tatiana, 2003, The Value of Corporate Votes and Control Benefits: A Cross Country Analysis, Journal of Financial Economics 68, 325-351.

Reese, William, and Michael Weisbach, 2002, Protection of Minority Shareholder Interests, Cross Listings in the United States, and Subsequent Equity Offerings, Journal of Financial Economics 66, 65-104.

Shleifer, A., and R. Vishny, 1986, Large Shareholders and Corporate Control, Journal of Political Economy 94, 461-488. 
Stulz, René, 1988, Managerial Control of Voting Rights, Journal of Financial Economics 20, 2559.

Verrecchia, Robert, 1999, Disclosure and the Cost of Capital: A discussion, Journal of Accounting and Economics 26, 271-283. 


\section{Table 1}

\section{Basic Summary Statistics by Country}

U.S. Investment, obtained from AHSW, is the percent of the firm's float, and, alternatively, market capitalization, that was held by U.S. portfolio investors as of end-1997. Float is the percentage of shares not held by large blockholders (as given by Worldscope's Closely Held variable) multiplied by the market value of equity in billions of U.S. dollars. Size is the value of FY1997 total assets in millions of U.S. dollars. Ownership data list the median value of total direct and indirect control rights held by blockholder type. Family/Management (Mgmt) refers to total control rights held by family groups and the top management group. Other Blockholders $(\mathrm{BH})$ refers to total control rights held by blockholders other than Family/Management. Ownership structure data are obtained from Claessens, Djankov, and Lang (2000), Faccio and Lang (2002), and Lins (2003). N is the number of firms that have data on ownership structure, end-1997 market capitalization from Datastream, and basic balance sheet variables from Worldscope. Numbers in parentheses indicate the smaller sample sizes for data on the frequency that Family/Mgmt control is greater than control by any other type of BH.

\begin{tabular}{|c|c|c|c|c|c|c|c|c|}
\hline \multirow[b]{2}{*}{ Country } & \multirow[b]{2}{*}{$\mathrm{N}$} & \multicolumn{2}{|c|}{ U.S. Investment } & \multirow{2}{*}{\begin{tabular}{l}
\multicolumn{1}{c}{$\begin{array}{c}\text { Size } \\
\text { (Total } \\
\text { assets) }\end{array}$} \\
$\begin{array}{l}\text { \$millions } \\
\text { (mean) }\end{array}$
\end{tabular}} & \multirow{2}{*}{$\begin{array}{c}\text { Family/ } \\
\text { Mgmt } \\
\text { Control } \\
\% \\
\text { (median) }\end{array}$} & \multirow[b]{2}{*}{$\begin{array}{c}\text { Other BH } \\
\text { Control } \\
\% \\
\text { (median) } \\
\end{array}$} & \multicolumn{2}{|c|}{$\begin{array}{l}\frac{\text { Frequency }(\%) \text { that }}{\text { Family/Mgmt Control }} \\
\text { is: }\end{array}$} \\
\hline & & $\begin{array}{l}\% \text { of } \\
\text { float } \\
\text { (mean) }\end{array}$ & $\begin{array}{c}\% \text { of } \\
\text { market cap } \\
\text { (mean) }\end{array}$ & & & & $\begin{array}{c}\text { Greater } \\
\text { than any } \\
\text { other BH }\end{array}$ & $\begin{array}{l}\text { Greater } \\
\text { than } 50 \%\end{array}$ \\
\hline Argentina & 6 & 54.0 & 23.0 & 4595 & 0 & 57 & 17 & 0 \\
\hline Austria & 23 & 12.7 & 6.4 & 1429 & 38 & 0 & 52 & 43 \\
\hline Belgium & 57 & 3.5 & 1.8 & 2275 & 45 & 0 & 72 & 42 \\
\hline Brazil & 16 & 27.0 & 10.4 & 6408 & 0 & 22 & $25(8)$ & 13 \\
\hline Chile & 39 & 11.7 & 5.5 & 1323 & 0 & 0 & 89 (19) & 21 \\
\hline Czech Republic & 6 & 13.9 & 3.2 & 169 & 0 & 5 & $67(3)$ & 17 \\
\hline Finland & 60 & 9.9 & 6.6 & 913 & 23 & 0 & 58 & 25 \\
\hline France & 359 & 7.5 & 3.9 & 2205 & 51 & 0 & 83 & 55 \\
\hline Germany & 375 & 4.9 & 2.2 & 2383 & 56 & 0 & 82 & 60 \\
\hline Hong Kong & 183 & 11.2 & 5.2 & 1035 & 42 & 0 & 80 (169) & 40 \\
\hline Indonesia & 19 & 10.5 & 3.5 & 217 & 0 & 7 & $64(11)$ & 32 \\
\hline Ireland & 37 & 8.4 & 5.5 & 390 & 0 & 12 & 30 & 8 \\
\hline Israel & 7 & 19.9 & 8.8 & 1647 & 50 & 0 & 71 & 57 \\
\hline Italy & 53 & 9.0 & 4.0 & 4063 & 45 & 0 & 72 & 43 \\
\hline Japan & 979 & 3.5 & 2.0 & 3012 & 0 & 10 & 14 & 0 \\
\hline Korea (South) & 165 & 4.5 & 3.0 & 1996 & 14 & 5 & $75(150)$ & 1 \\
\hline Malaysia & 250 & 4.6 & 2.3 & 586 & 30 & 16 & $71(236)$ & 18 \\
\hline Norway & 90 & 9.4 & 6.4 & 799 & 25 & 0 & 61 & 16 \\
\hline Philippines & 20 & 13.7 & 4.3 & 324 & 3 & 0 & $67(9)$ & 15 \\
\hline Portugal & 32 & 11.2 & 5.5 & 744 & 49 & 0 & $84(31)$ & 50 \\
\hline Singapore & 133 & 7.1 & 3.2 & 611 & 29 & 21 & 65 (126) & 33 \\
\hline South Africa & 102 & 8.0 & 3.4 & 775 & 7 & 9 & $57(82)$ & 41 \\
\hline Spain & 63 & 8.4 & 4.6 & 2083 & 27 & 0 & 59 & 30 \\
\hline Sweden & 136 & 9.2 & 6.4 & 1328 & 22 & 0 & 59 & 21 \\
\hline Switzerland & 84 & 9.8 & 5.6 & 1390 & 50 & 0 & 73 & 50 \\
\hline Taiwan & 9 & 1.8 & 1.4 & 659 & 0 & 0 & $100(4)$ & 0 \\
\hline Thailand & 14 & 13.3 & 3.4 & 372 & 25 & 10 & $69(13)$ & 14 \\
\hline Turkey & 16 & 32.8 & 10.8 & 211 & 19 & 48 & 44 & 38 \\
\hline UK & 1077 & 5.7 & 4.2 & 1010 & 11 & 0 & 47 & 11 \\
\hline Total & 4410 & 6.4 & 3.6 & 1755 & 13 & 5 & $53(4283)$ & 22 \\
\hline Europe & 2468 & 6.9 & 4.2 & 1519 & 22 & 0 & $62(2464)$ & 30 \\
\hline Latin America & 61 & 19.8 & 8.5 & 2978 & 0 & 0 & $61(33)$ & 16 \\
\hline Emerging Asia & 800 & 7.1 & 3.4 & 975 & 25 & 7 & $73(725)$ & 23 \\
\hline Other & 1081 & 3.9 & 2.2 & 2800 & 0 & 10 & $17(1061)$ & 4 \\
\hline
\end{tabular}




\section{Table 2}

\section{U.S. Investment, Blockholder Control, and Legal Origin}

Tobit regression estimates of U.S. Investment scaled by float on blockholder control variables of interest and controls estimated on subsamples of countries without and with an English Common Law legal origin as indicated in Table 2 of LLSV (1998). U.S. Investment is as of end-1997 and is defined the dollar value of U.S. investors' portfolio holdings as a share of float, where float is defined as the percentage of shares not held by large blockholders (as given by Worldscope's Closely Held variable) multiplied by the market value of equity in billions of U.S. dollars. The first four blockholder variables of interest are the percentage of control rights held by family groups and the top management group (Family/Mgmt control) and indicator variables that take on the value of one if Family/Mgmt control rights in the firm are greater than (GT) the median level of Family/Mgmt control rights in the country, if Family/Mgmt group control is greater than the country median level and the Family/Mgmt group is the largest blockholder (BH), or if the Family/Mgmt group controls more than 50 percent of the outstanding shares. The final two blockholder variables pertain to outside blockholder control: the percentage held by Other BHs and an indicator variable that takes on the value of one if Other $\mathrm{BHs}$ control more than 50 percent of the outstanding shares. XLIST is an indicator variable that takes on the value one if the firm's equity is listed on a U.S. exchange. $\mathrm{Ln}$ (Size) is the log of total assets in millions of U.S. dollars. Leverage is the ratio of total liabilities to total assets. Book-to-market is book equity value over market equity value. Dividend yield is the preceding twelve months dividends paid over price. Financial variables are from Worldscope and are for fiscal year 1997. Indicator variables for countries and industry groups (based on the classification of Campbell, 1996) are included but not reported. For each coefficient, the p-value of the two-tailed t-test of equality with zero is reported in parentheses. At the bottom of Panel B, we report the p-value of the difference in coefficients on the blockholder variable of interest in the non-English and English legal origin subsamples.

Panel A: Not English Common Law

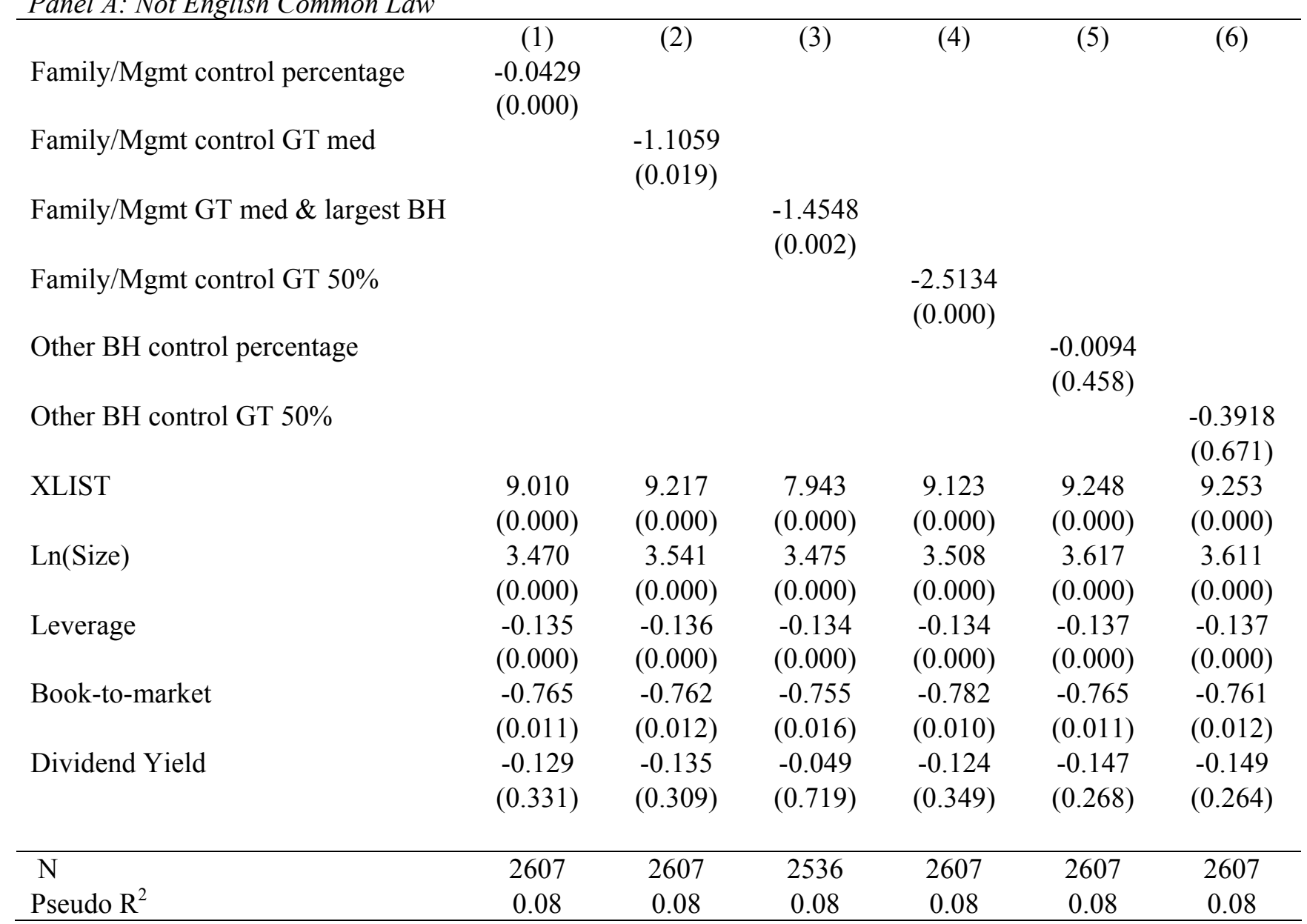


Panel B: English Common Law

(1)

(2)

(3)

(4)

(5)

(6)

Family/Mgmt control percentage

0.0041

$(0.738)$

Family/Mgmt control GT med

0.9441

(0.089)

Family/Mgmt GT med \& largest BH

0.7043

(0.216)

Family/Mgmt control GT 50\%

0.6472

$(0.385)$

Other BH control percentage

0.0213

(0.139)

Other BH control GT 50\%

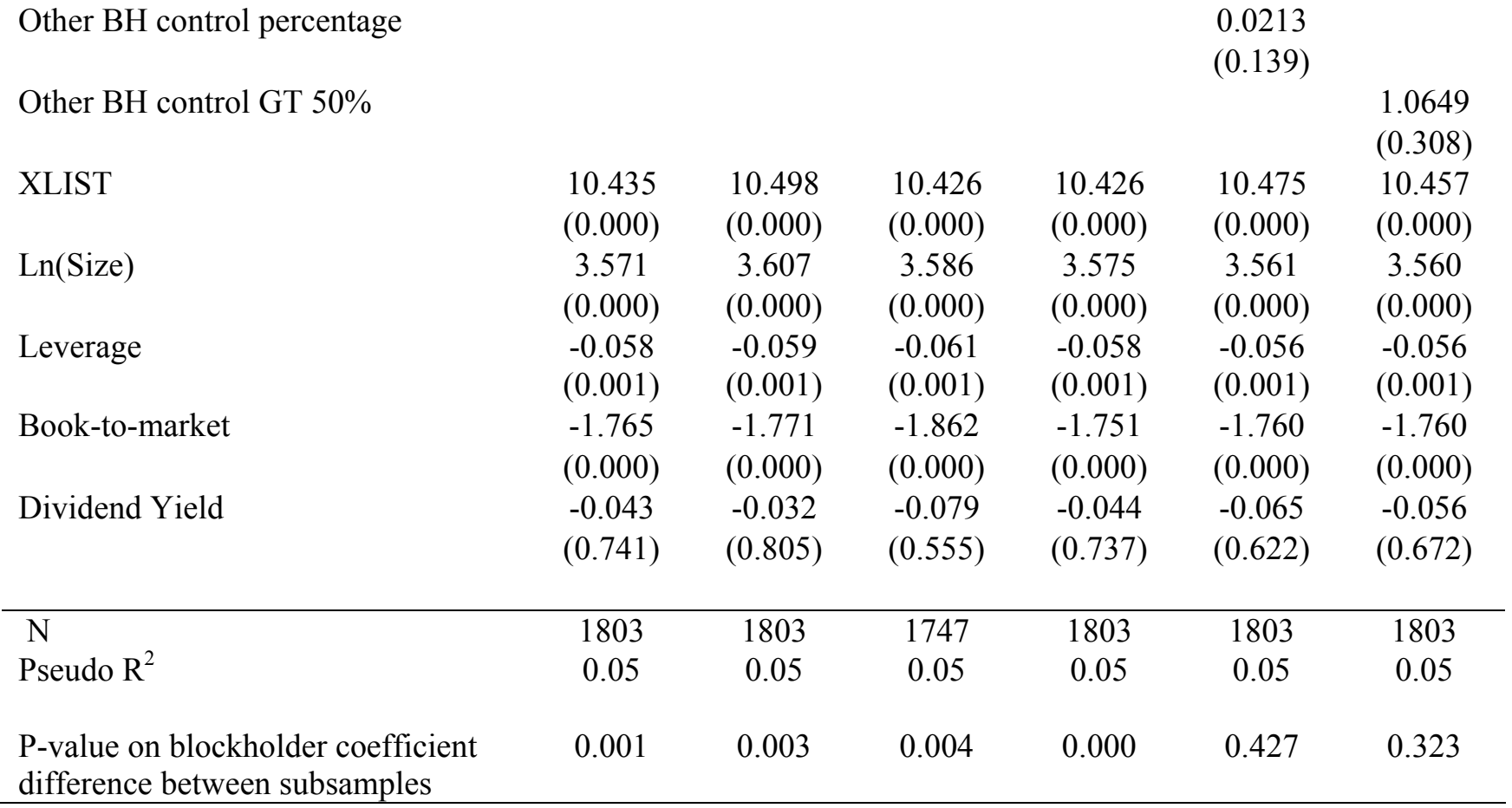




\section{Table 3}

\section{U.S. Investment, Blockholder Control, and Private Enforcement}

Tobit regression estimates of U.S. Investment scaled by float estimated on subsamples of countries with low and high standardization of the private contracting framework as measured by Private Enforcement. "Private Enforcement" values potentially range from 0 to 1 and are defined as the average of the Disclosure Requirements and Liability Standards indexes, which are obtained from Table 2 of La Porta, Lopez-de-Silanes, and Shleifer (2004). The "Low Private Enforcement" subsample contains countries that score below our sample average of 0.6 on the Private Enforcement measure. U.S. Investment is as of end-1997 and is defined the dollar value of U.S. investors' portfolio holdings as a share of float, where float is as defined in Table 2. Other model variables are described previously in Table 2. Indicator variables for countries and industry groups (based on the classification of Campbell, 1996) are included but not reported. For each coefficient, the p-value of the two-tailed t-test of equality with zero is reported in parentheses. At the bottom of Panel B, we report the p-value of the difference in coefficients on the blockholder variable of interest in the low and high Private Enforcement subsamples.

Panel A: Low Private Enforcement

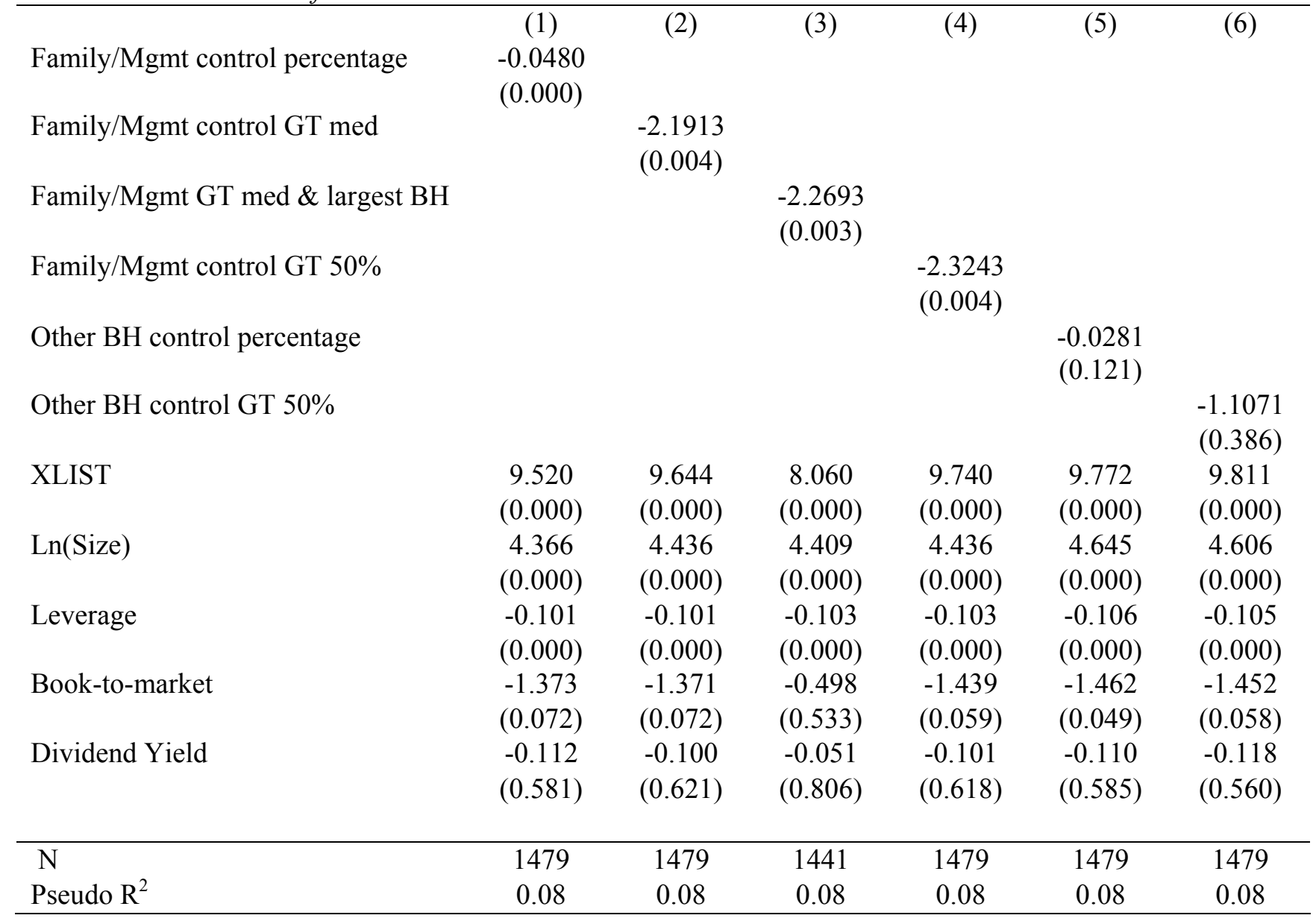


Panel B: High Private Enforcement

Panel B: High Private Enforcement (1)

(2)

0.0042

$(0.666)$

(3)

(4)

(5)

(6)

Family/Mgmt control percentage

(0.66)

0.9679

Family/Mgmt control GT med

(0.013)

Family/Mgmt GT med \& largest BH

0.7012

(0.083)

Family/Mgmt control GT 50\%

0.3757

$(0.545)$

Other BH control percentage

0.0233

(0.036)

Other BH control GT 50\%

1.2533

$(0.129)$

XLIST

9.645

9.657

9.636

9.646

9.650

$(0.000)$

(0.000)

$(0.000)$

$(0.000)$

9.660

$(0.000)$

$\operatorname{Ln}($ Size $)$

3.149

3.189

3.131

3.146

(0.000)

3.137

Leverage

$(0.000)$

(0.000)

$(0.000)$

$(0.000)$

3.144

$(0.000)$

$-0.101$

$-0.102$

$-0.100$

$-0.101$

(0.000)

$-0.100$

(0.000)

(0.000)

(0.000)

(0.000)

$-0.100$

$(0.000)$

Book-to-market

$-1.116$

$-1.118$

$-1.304$

$-1.111$

(0.000)

(0.000)

$\begin{array}{llllll}(0.000) & (0.000) & (0.000) & (0.000) & (0.000) & (0.000)\end{array}$

Dividend Yield

$-0.091$

$-0.083$

$-0.093$

$-0.092$

$-0.109$

$-0.101$

(0.360)

(0.404)

(0.355)

(0.356)

(0.271)

(0.307)

\begin{tabular}{lcccccc}
\hline $\mathrm{N}$ & 2925 & 2925 & 2839 & 2925 & 2925 & 2925 \\
Pseudo R & 0.05 & 0.05 & 0.06 & 0.05 & 0.05 & 0.05 \\
& & & & & & \\
& 0.002 & 0.000 & 0.000 & 0.011 & 0.217 & 0.118 \\
$\begin{array}{l}\text { P-value on blockholder coefficient } \\
\text { difference between subsamples }\end{array}$ & & & & & & \\
\hline
\end{tabular}




\section{Table 4}

\section{U.S. Investment, Blockholder Control, and Antidirector Rights}

Tobit regression estimates of U.S. Investment scaled by float estimated on subsamples of countries with low and high shareholder rights as measured by Antidirector Rights. "Antidirector Rights" values range from 0 to 5 and are obtained from Table 2 of LLSV (1998). The "Low Antidirector Rights" subsample contains countries that score below 4 on the Antidirector Rights measure. U.S. Investment is as of end-1997 and is defined the dollar value of U.S. investors' portfolio holdings as a share of float, where float is as defined in Table 2. Other model variables are described previously in Table 2. Indicator variables for countries and industry groups (based on the classification of Campbell, 1996) are included but not reported. For each coefficient, the p-value of the two-tailed t-test of equality with zero is reported in parentheses. At the bottom of Panel B, we report the p-value of the difference in coefficients on the blockholder variable of interest in the low and high Antidirector Rights subsamples.

Panel A: Low Antidirector Rights

$\begin{array}{lllll}(1) & (2) & (3)\end{array}$

Family/Mgmt control percentage $\quad-0.0453$

$(0.001)$

Family/Mgmt control GT med

Family/Mgmt GT med \& largest BH

Family/Mgmt control GT 50\%

$-1.8986$

(0.011)

$-2.5926$

$(0.002)$

Other BH control percentage

$-0.0331$

(0.075)

Other BH control GT 50\%

$-1.3406$

$(0.319)$

XLIST

$\operatorname{Ln}($ Size $)$

Leverage

Book-to-market

Dividend Yield

$\begin{array}{cccccc}6.997 & 7.156 & 7.635 & 7.146 & 7.238 & 7.275 \\ (0.001) & (0.001) & (0.000) & (0.001) & (0.001) & (0.001)\end{array}$

$\begin{array}{llllll}4.162 & 4.256 & 4.144 & 4.208 & 4.434 & 4.388\end{array}$

$\begin{array}{llllll}(0.000) & (0.000) & (0.000) & (0.000) & (0.000) & (0.000)\end{array}$

$\begin{array}{llllll}-0.136 & -0.137 & -0.131 & -0.136 & -0.140 & -0.139\end{array}$

$\begin{array}{llllll}(0.000) & (0.000) & (0.000) & (0.000) & (0.000) & (0.000)\end{array}$

$\begin{array}{llllll}-0.366 & -0.369 & -0.462 & -0.384 & -0.402 & -0.382\end{array}$

$\begin{array}{llllll}(0.413) & (0.409) & (0.330) & (0.389) & (0.369) & (0.394)\end{array}$

$\begin{array}{llllll}-0.247 & -0.249 & -0.165 & -0.248 & -0.270 & -0.270\end{array}$

$\begin{array}{lllll}(0.189) & (0.186) & (0.390) & (0.186) & (0.151)\end{array}$

\begin{tabular}{lllllll}
\hline $\mathrm{N}$ & 1445 & 1445 & 1396 & 1445 & 1445 & 1445 \\
Pseudo R & 0.07 & 0.07 & 0.07 & 0.07 & 0.07 & 0.07 \\
\hline
\end{tabular}


Panel B: High Antidirector Rights

Family/Mgmt control percentage

(1)

(2)

(3)

(4)

(5)

(6)

$-0.0050$

$(0.595)$

0.6163

$(0.124)$

Family/Mgmt GT med \& largest BH

0.4576

(0.271)

Family/Mgmt control GT 50\%

0.1620

$(0.788)$

Other BH control percentage

0.0239

(0.030)

Other BH control GT 50\%

.1595

$(0.147)$

XLIST

11.293

11.319

10.275

11.304

11.297

11.291

$\operatorname{Ln}($ Size $)$

$(0.000)$

(0.000)

$(0.000)$

$(0.000)$

$(0.000) \quad(0.000)$

3.161

3.200

3.208

3.173

3.173

3.165

Leverage

(0.000)

$(0.000) \quad(0.000)$

$(0.000)$

$(0.000) \quad(0.000)$

$-0.093$

$-0.094$

$-0.096$

$-0.094$

$-0.092$

$-0.092$

(0.000)

(0.000)

(0.000)

$(0.000)$

$(0.000)$

$(0.000)$

Book-to-market

$-1.773$

$-1.777$

$-1.750$

$-1.771$

$-1.761$

$-1.764$

$(0.000)$

(0.000)

$(0.000)$

$(0.000)$

$(0.000) \quad(0.000)$

Dividend Yield

$-0.019$

$-0.009$

$-0.030$

$-0.016$

$-0.038$

$-0.026$

$(0.855)$

(0.930)

(0.777)

$(0.822)$

$(0.715)$

$(0.805)$

\begin{tabular}{lcccccc}
\hline $\mathrm{N}$ & 2959 & 2959 & 2884 & 2959 & 2959 & 2959 \\
Pseudo R & 0.06 & 0.06 & 0.06 & 0.06 & 0.06 & 0.06 \\
& & & & & & \\
$\begin{array}{l}\text { P-value on blockholder coefficient } \\
\text { difference between subsamples }\end{array}$ & 0.021 & 0.008 & 0.005 & 0.008 & 0.160 & 0.102 \\
\hline
\end{tabular}




\section{Table 5}

\section{Full Sample Tests of U.S. Investment and Blockholder Control}

Tobit regression estimates of U.S. Investment on blockholder variables of interest and controls for the full sample of 4410 firms from 29 countries. U.S. Investment is as of end-1997 and is defined the dollar value of U.S. investors' portfolio holdings as a share of float, where float is defined as the percentage of shares not held by large blockholders (as given by Worldscope's Closely Held variable) multiplied by the market value of equity in billions of U.S. dollars. Other model variables are described previously in Table 2. Indicator variables for countries and industry groups (based on the classification of Campbell, 1996) are included but not reported. For each coefficient, the p-value of the two-tailed t-test of equality with zero is reported in parentheses.

\begin{tabular}{|c|c|c|c|c|c|c|}
\hline Family/Mgmt control percentage & $\begin{array}{c}(1) \\
-0.0213 \\
(0.006)\end{array}$ & (2) & (3) & (4) & (5) & (6) \\
\hline Family/Mgmt control GT med & & $\begin{array}{c}-0.0966 \\
(0.788)\end{array}$ & & & & \\
\hline Family/Mgmt GT med \& largest BH & & & $\begin{array}{l}-0.3650 \\
(0.320)\end{array}$ & & & \\
\hline Family/Mgmt control GT 50\% & & & & $\begin{array}{r}-1.0648 \\
(0.025)\end{array}$ & & \\
\hline Other $\mathrm{BH}$ control percentage & & & & & $\begin{array}{l}0.0046 \\
(0.627)\end{array}$ & \\
\hline Other BH control GT 50\% & & & & & & $\begin{array}{l}0.3009 \\
(0.663)\end{array}$ \\
\hline XLIST & $\begin{array}{c}9.972 \\
(0.000)\end{array}$ & $\begin{array}{l}10.018 \\
(0.000)\end{array}$ & $\begin{array}{c}9.395 \\
(0.000)\end{array}$ & $\begin{array}{l}10.010 \\
(0.000)\end{array}$ & $\begin{array}{l}10.027 \\
(0.000)\end{array}$ & $\begin{array}{l}10.023 \\
(0.000)\end{array}$ \\
\hline $\operatorname{Ln}($ Size $)$ & $\begin{array}{c}3.554 \\
(0.000)\end{array}$ & $\begin{array}{c}3.612 \\
(0.000)\end{array}$ & $\begin{array}{c}3.568 \\
(0.000)\end{array}$ & $\begin{array}{c}3.582 \\
(0.000)\end{array}$ & $\begin{array}{c}3.614 \\
(0.000)\end{array}$ & $\begin{array}{c}3.614 \\
(0.000)\end{array}$ \\
\hline Leverage & $\begin{array}{l}-0.107 \\
(0.000)\end{array}$ & $\begin{array}{l}-0.108 \\
(0.000)\end{array}$ & $\begin{array}{c}-0.107 \\
(0.000)\end{array}$ & $\begin{array}{l}-0.107 \\
(0.000)\end{array}$ & $\begin{array}{c}-0.108 \\
(0.000)\end{array}$ & $\begin{array}{c}-0.108 \\
(0.000)\end{array}$ \\
\hline Book-to-market & $\begin{array}{l}-1.166 \\
(0.000)\end{array}$ & $\begin{array}{l}-1.168 \\
(0.000)\end{array}$ & $\begin{array}{c}-1.199 \\
(0.000)\end{array}$ & $\begin{array}{l}-1.182 \\
(0.000)\end{array}$ & $\begin{array}{l}-1.167 \\
(0.000)\end{array}$ & $\begin{array}{l}-1.168 \\
(0.000)\end{array}$ \\
\hline Dividend Yield & $\begin{array}{c}-0.096 \\
(0.296)\end{array}$ & $\begin{array}{l}-0.094 \\
(0.307)\end{array}$ & $\begin{array}{l}-0.087 \\
(0.355)\end{array}$ & $\begin{array}{l}-0.091 \\
(0.322)\end{array}$ & $\begin{array}{l}-0.096 \\
(0.297)\end{array}$ & $\begin{array}{l}-0.095 \\
(0.302)\end{array}$ \\
\hline $\mathrm{N}$ & 4410 & 4410 & 4283 & 4410 & 4410 & 4410 \\
\hline Pseudo $\mathrm{R}^{2}$ & 0.06 & 0.06 & 0.06 & 0.06 & 0.06 & 0.06 \\
\hline
\end{tabular}




\section{Table 6}

\section{Full Sample Tests of U.S. Investment Scaled by Market Capitalization}

Tobit regression estimates of U.S. Investment on disclosure variables of interest and controls for the full sample of 4410 firms from 29 countries. U.S. Investment is as of end-1997 and is defined the dollar value of U.S. investors' portfolio holdings as a share of market capitalization. Ln(Float) is the percentage of shares not held by large blockholders (as given by Worldscope's Closely Held variable) multiplied by the log of the market value of equity in billions of U.S. dollars. Other model variables are described previously in Table 2. Indicator variables for countries and industry groups (based on the classification of Campbell, 1996) are included but not reported. For each coefficient, the p-value of the two-tailed $\mathrm{t}$-test of equality with zero is reported in parentheses.

\begin{tabular}{|c|c|c|c|c|c|c|}
\hline Family/Mgmt control percentage & $\begin{array}{c}(1) \\
-0.0190 \\
(0.000)\end{array}$ & (2) & (3) & (4) & (5) & (6) \\
\hline Family/Mgmt control GT med & & $\begin{array}{c}-0.3429 \\
(0.081)\end{array}$ & & & & \\
\hline Family/Mgmt GT med \& largest BH & & & $\begin{array}{l}-0.4685 \\
(0.022)\end{array}$ & & & \\
\hline Family/Mgmt control GT 50\% & & & & $\begin{array}{r}-1.1228 \\
(0.000)\end{array}$ & & \\
\hline Other $\mathrm{BH}$ control percentage & & & & & $\begin{array}{l}0.0000 \\
(0.993)\end{array}$ & \\
\hline Other BH control GT 50\% & & & & & & $\begin{array}{c}-0.2600 \\
(0.491)\end{array}$ \\
\hline XLIST & $\begin{array}{c}6.392 \\
(0.000)\end{array}$ & $\begin{array}{c}6.379 \\
(0.000)\end{array}$ & $\begin{array}{c}6.133 \\
(0.000)\end{array}$ & $\begin{array}{c}6.410 \\
(0.000)\end{array}$ & $\begin{array}{c}6.377 \\
(0.000)\end{array}$ & $\begin{array}{c}6.381 \\
(0.000)\end{array}$ \\
\hline Ln(Float) & $\begin{array}{c}2.125 \\
(0.000)\end{array}$ & $\begin{array}{c}2.171 \\
(0.000)\end{array}$ & $\begin{array}{c}2.172 \\
(0.000)\end{array}$ & $\begin{array}{c}2.146 \\
(0.000)\end{array}$ & $\begin{array}{c}2.192 \\
(0.000)\end{array}$ & $\begin{array}{c}2.192 \\
(0.000)\end{array}$ \\
\hline Leverage & $\begin{array}{c}-0.014 \\
(0.012)\end{array}$ & $\begin{array}{l}-0.014 \\
(0.012)\end{array}$ & $\begin{array}{c}-0.014 \\
(0.008)\end{array}$ & $\begin{array}{l}-0.014 \\
(0.012)\end{array}$ & $\begin{array}{c}-0.013 \\
(0.0013\end{array}$ & $\begin{array}{l}-0.014 \\
(0.011)\end{array}$ \\
\hline Book-to-market & $\begin{array}{c}0.466 \\
(0.001)\end{array}$ & $\begin{array}{c}0.495 \\
(0.000)\end{array}$ & $\begin{array}{c}0.482 \\
(0.001)\end{array}$ & $\begin{array}{c}0.462 \\
(0.001)\end{array}$ & $\begin{array}{c}0.505 \\
(0.000)\end{array}$ & $\begin{array}{c}0.504 \\
(0.000)\end{array}$ \\
\hline Dividend Yield & $\begin{array}{c}-0.031 \\
(0.529)\end{array}$ & $\begin{array}{l}-0.030 \\
(0.555)\end{array}$ & $\begin{array}{c}-0.030 \\
(0.567)\end{array}$ & $\begin{array}{l}-0.026 \\
(0.608)\end{array}$ & $\begin{array}{c}-0.027 \\
(0.585)\end{array}$ & $\begin{array}{l}-0.026 \\
(0.602)\end{array}$ \\
\hline $\mathrm{N}$ & 4410 & 4410 & 4283 & 4410 & 4410 & 4410 \\
\hline Pseudo $\mathrm{R}^{2}$ & 0.10 & 0.10 & 0.10 & 0.10 & 0.10 & 0.10 \\
\hline
\end{tabular}




\section{Table 7}

\section{Tests of U.S. Investment Scaled by Market Capitalization in Low and High Protection Subsamples}

Tobit regressions are the same as in Table 6 but are for the low and high protection subsamples as defined in Tables $3-5$. For the sake of brevity, we report only the coefficient estimates on the blockholder variables of interest. For each coefficient, the p-value of the two-tailed t-test of equality with zero is reported in parentheses. In italics, we report the pvalue of the difference in coefficients on the blockholder variable of interest in the low and high protection subsamples.

\begin{tabular}{|c|c|c|c|c|c|c|}
\hline & $\begin{array}{c}(1) \\
\text { Family/Mgmt } \\
\text { control } \\
\text { percentage }\end{array}$ & $\begin{array}{c}(2) \\
\text { Family/Mgmt } \\
\text { control GT } \\
\text { med }\end{array}$ & $\begin{array}{c}(3) \\
\text { Family/Mgmt } \\
\text { GT med \& } \\
\text { largest BH }\end{array}$ & $\begin{array}{c}(4) \\
\text { Family/Mgmt } \\
\text { control GT } \\
50 \%\end{array}$ & $\begin{array}{c}\text { (5) } \\
\text { Other BH } \\
\text { control } \\
\text { percentage }\end{array}$ & $\begin{array}{c}(6) \\
\text { Other BH } \\
\text { control } \\
\text { GT } 50 \%\end{array}$ \\
\hline Low Shareholder Rights & $\begin{array}{l}-0.026 \\
(0.000)\end{array}$ & $\begin{array}{l}-1.099 \\
(0.004)\end{array}$ & $\begin{array}{l}-1.187 \\
(0.002)\end{array}$ & $\begin{array}{c}-1.698 \\
(0.000)\end{array}$ & $\begin{array}{l}-0.011 \\
(0.248)\end{array}$ & $\begin{array}{l}-0.583 \\
(0.388)\end{array}$ \\
\hline High Shareholder Rights & $\begin{array}{l}-0.012 \\
(0.029)\end{array}$ & $\begin{array}{c}0.080 \\
(0.728)\end{array}$ & $\begin{array}{l}-0.015 \\
(0.949)\end{array}$ & $\begin{array}{c}-0.454 \\
(0.194)\end{array}$ & $\begin{array}{c}0.003 \\
(0.652)\end{array}$ & $\begin{array}{c}-0.190 \\
(0.680)\end{array}$ \\
\hline p-value of difference & $(0.095)$ & $(0.005)$ & $(0.006)$ & $(0.015)$ & $(0.398)$ & $(0.613)$ \\
\hline Not English Common Law & $\begin{array}{c}-0.030 \\
(0.000)\end{array}$ & $\begin{array}{c}-0.898 \\
(0.000)\end{array}$ & $\begin{array}{c}-1.062 \\
(0.000)\end{array}$ & $\begin{array}{c}-1.907 \\
(0.000)\end{array}$ & $\begin{array}{c}-0.004 \\
(0.526)\end{array}$ & $\begin{array}{c}-0.624 \\
(0.200)\end{array}$ \\
\hline $\begin{array}{l}\text { English Common Law } \\
\text { p-value of difference }\end{array}$ & $\begin{array}{l}-0.007 \\
(0.286) \\
(0.005)\end{array}$ & $\begin{array}{c}0.223 \\
(0.476) \\
(0.003)\end{array}$ & $\begin{array}{c}0.112 \\
(0.728) \\
(0.003)\end{array}$ & $\begin{array}{l}-0.234 \\
(0.580) \\
(0.001)\end{array}$ & $\begin{array}{c}0.004 \\
(0.597) \\
(0.948)\end{array}$ & $\begin{array}{c}0.091 \\
(0.877) \\
(0.393)\end{array}$ \\
\hline Low Private Enforcement & $\begin{array}{l}-0.026 \\
(0.000)\end{array}$ & $\begin{array}{l}-1.457 \\
(0.000)\end{array}$ & $\begin{array}{c}-1.466 \\
(0.000)\end{array}$ & $\begin{array}{c}-1.454 \\
(0.001)\end{array}$ & $\begin{array}{c}-0.009 \\
(0.344)\end{array}$ & $\begin{array}{l}-0.354 \\
(0.590)\end{array}$ \\
\hline High Private Enforcement & $\begin{array}{c}-0.006 \\
(0.246) \\
(0.015)\end{array}$ & $\begin{array}{c}0.309 \\
(0.162) \\
(0.000)\end{array}$ & $\begin{array}{c}0.193 \\
(0.404) \\
(0.000)\end{array}$ & $\begin{array}{c}-0.362 \\
(0.303) \\
(0.030)\end{array}$ & $\begin{array}{c}0.003 \\
(0.613) \\
(0.570)\end{array}$ & $\begin{array}{l}-0.161 \\
(0.730) \\
(0.785)\end{array}$ \\
\hline
\end{tabular}

